Рекомендована д. фрармац. наук, профр. Д. І. Дмитрієвським

УДК 615. 014.21:616.379-008.64 615. 014.21:616.379-008.64

DOI 10.11603/2312-0967.2018.1.8609

\title{
ВИВЧЕННЯ ВПЛИВУ ДОПОМІЖНИХ РЕЧОВИН НА ФАРМАКО-ТЕХНОЛОГІЧНІ ВЛАСТИВОСТІ ТАБЛЕТОК ЕКСТРАКТУ ЧОРНИЦІ ЛИСТЯ, ЕКСТРАКТУ КОЗЛЯТНИКА ТРАВИ ТА ТАУРИНУ, ОТРИМАНИХ МЕТОДОМ ПРЯМОГО ПРЕСУВАННЯ
}

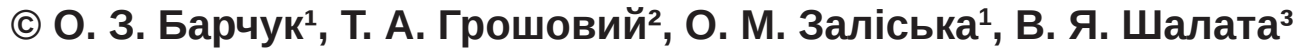

Львівський національний медичний університет імені Данила Галицького ${ }^{1}$ ДВНЗ «Тернопільський державний медичний університет імені І. Я. Горбачевського МОЗ України»² ПАТ «Галичфрарм»³ olvia2003@ukr.net

\begin{abstract}
Мета роботи. Дослідження впливу допоміжних речовин на фрармако-технологічні показники таблеток 3 метою розробки нового комбінованого лікарського засобу з гіпоглікемічною активністю на основі сухого екстракту чорниці листя, екстракту козлятника трави та таурину методом прямого пресування.

Матеріали і методи. Основні діючі речовини - сухі екстракти 3 листя чорниці звичайної і трави козлятника лікарського, таурин і 30 допоміжних речовин, згрупованих у 6 якісних фракторів за властивостями і призначенями. В роботі використовували математичне планування експерименту на основі гіпер-греко-латинського квадрату четвертого порядку, що дає можливість встановити залежність між складом таблеток та їх основними фармакотехнологічними показниками (процес пресування, однорідність маси, стійкість таблеток до роздавлювання, стираність, час розпадання), відповідно до вимог ДФУ 2.

Результати й обговорення. Вивчено вплив 30-ти допоміжних речовин на фрармако-технологічні властивості таблеток (процес пресування, однорідність маси, стійкість до роздавлювання, стираність, час розпадання) на основі сухих екстрактів чорниці листя, козлятника трави та таурину. За допомогою шестифакторного експерименту - гіпер-греколатинського квадрату четвертого порядку вивчено вплив 6-ти якісних фракторів на фрармако-технологічні показники досліджуваних таблеток. Для кожного із показників побудовані ранжовані ряди переваг вивчених допоміжних речовин. Дисперсійний аналіз експериментальних даних показав, що найкраще процес пресування таблеток екстракту чорниці листя, екстракту козлятника трави і таурину проходить при використанні парлітол 100SD+манітолу, кислоти стеаринової, неусиліну УФЛ і натрій крохмальгліколяту.

Найбільш однорідну масу таблеток отримано при використанні неусиліну Ус 2 та неусиліну УФЛ, натрій карбоксиметилкрохмалю, просолву Одт г 2, магнію стеарату та олії гідрогенізованої.

Найбільш стійкі до роздавлювання таблетки отримували при використанні МКЦ 200, МКЦ бурст, магнію стеарату, неусиліну УС 2, натрію кроскармелози та натрій карбоксиметилкрохмалю.

Найменшу стираність мали досліджувані таблетки, до складу яких входила МКЦ бурст, неусилін УС 2, МКЦ 200, кросповідон ХЛ 10, кислота стеаринова і лудіпрес.

Найшвидше розпадалися таблетки екстракту чорниці листя, екстракту козлятника трави і таурину при використанні маніту, таблетози, натрій кроскармелози, кальцію карбонату, натрій стеарилфумарату, МКЦ 102, просолву ОДТ Г 2. Висновки. Дослідженно вплив 30-ти допоміжних речовин на фрармако-технологічні властивості таблеток екстракту чорниці листя, екстракту козлятника трави і таурину (процес пресування, однорідність маси, стійкість до роздавлювання, стираність і розпадання). За допомогою гіпер-греко-латинського квадрату четвертого порядку вивчено вплив 6-ти якісних фракторів на основні відгуки (показники) таблеток екстракту чорниці листя, екстракту козлятника трави і таурину. Побудовані ранжовані ряди переваг впливу ДР на 5 відгуків (показників) таблеток екстракту чорниці листя, екстракту козлятника трави і таурину.
\end{abstract}

Ключові слова: фрармако-технологічні показники таблеток; таблетки; чорниця звичайна; козлятник лікарський; таурин; цукровий діабет.

Повідомлення 2. Вивчення впливу допоміжних речовин на фармако-технологічні характеристики таблеток екстракту чорниці листя, екстракту козлятника трави і таурину, які отримували методом прямого пресування.
Вступ. Цукровий діабет - це ендокринно-обмінне захворювання, в основі якого лежить абсолютна або відносна недостатність інсуліну, що веде до порушення усіх видів обміну речовин. Сучасна фрармацевтична промисловість, щораз частіше займається пошуком

ISSN 2312-0967. Pharmaceutical review. 2018. № 1 
Фармацевтична технологія, біофармація, гомеопатія Pharmaceutical technology, biopharmacy, homeopathy

активних рослинних субстанцій для створення есективних комбінованих та монокомпонентних антидіабетичних препаратів [1]. Базуючись на наукові публікації, що доводять ефективну гіпоглікемічну дію козлятника лікарського та чорниці звичайної [2-6], доцільним і актуальним $€$ створення таблеток на основі даних рослинних екстрактів. Обґрунтування доцільності створення комбінованого лікарського засобу на основі екстракту чорниці, екстракту козлятника і таурину та дослідження впливу допоміжних речовин (ДР) на технологічні властивості порошкових мас трикомпонентної суміші наведено нами в науковій публікації [7]. Встановлено, що за впливом ДР на фрармако-технологічні властивості порошкових мас (плинність, кут природнього укосу, вільну насипну густину, насипну масу після ущільнення, процес засипки порошковою масою матриці таблеткової машини) та середню масу табле- ток екстракту чорниці листя, екстракту козлятника трави і таурину, можна прогнозувати отримання таблеток методом прямого пресування.

Мета роботи - вивчення впливу шести груп допоміжних речовин на фрармако-технологічні властивості таблеток (процес пресування, однорідність маси, стійкість до роздавлювання, стираність, час розпадання) 3 метою розробки нового комбінованого лікарського засобу з гіпоглікемічною активністю на основі сухих екстрактів із листя чорниці звичайної і трави козлятника лікарського та таурину.

Матеріали і методи. При проведенні досліджень використали сухі екстракти трави козлятника, листя чорниці звичайної, які отримані за технологією, яка описана в науковій роботі [8] і таурин виробництва Китай (серія 090708). Досліджували 30 ДР, перелік яких наведено в таблиці 1 повідомлення 1 [7], а саме:

Таблиця 1. Матриця планування експерименту на основі гіпер-греко-латинського квадрату четвертого порядку та результати дослідження таблеток екстракту трави козлятника, екстракту листя чорниці та таурину

\begin{tabular}{|c|c|c|c|c|c|c|c|c|c|c|c|c|c|c|c|c|}
\hline \multirow{2}{*}{$\begin{array}{l}\text { № } \\
\text { cepiï }\end{array}$} & \multicolumn{6}{|c|}{ Фактори } & \multicolumn{10}{|c|}{ Відгуки } \\
\hline & $A$ & $B$ & C & $D$ & $E$ & $F$ & $y_{7}$ & $\mathrm{y}_{7}^{\prime}$ & $\mathrm{y}_{8}$ & $\mathrm{y}_{8}^{\prime}$ & $y_{9}$ & $y_{9}^{\prime}$ & $\mathrm{y}_{10}$ & $\mathrm{y}_{10}^{\prime}$ & $y_{11}$ & $\mathrm{y}_{11}^{\prime}$ \\
\hline 1 & $a_{1}$ & $b_{1}$ & $C_{1}$ & $\mathrm{~d}_{1}$ & $e_{1}$ & $f_{1}$ & 3 & 4 & 4,02 & 4,45 & 30,66 & 28,66 & 4,23 & 3,81 & 13,4 & 14,0 \\
\hline 2 & $a_{1}$ & $b_{2}$ & $\mathrm{C}_{2}$ & $d_{2}$ & $\mathrm{e}_{2}$ & $f_{2}$ & 3 & 4 & 2,30 & 2,21 & 29,30 & 26,66 & 0,92 & 0,72 & 8,0 & 9,2 \\
\hline 3 & $a_{1}$ & $b_{3}$ & $\mathrm{C}_{3}$ & $\mathrm{~d}_{3}$ & $\mathrm{e}_{3}$ & $f_{3}$ & 4 & 5 & 2,92 & 2,64 & 78,33 & 81,00 & 0,33 & 0,24 & 18,5 & 19,1 \\
\hline 4 & $a_{1}$ & $\mathrm{~b}_{4}$ & $\mathrm{C}_{4}$ & $d_{4}$ & $\mathrm{e}_{4}$ & $\mathrm{f}_{4}$ & 3 & 3 & 2,46 & 2,38 & 61,06 & 64,00 & 0,34 & 0,31 & 17,1 & 16,4 \\
\hline 5 & $a_{1}$ & $b_{5}$ & $\mathrm{C}_{5}$ & $d_{5}$ & $e_{5}$ & $f_{5}$ & 4 & 4 & 2,93 & 2,58 & 18,06 & 21,00 & 11,2 & 9,11 & 12,4 & 13,2 \\
\hline 6 & $a_{2}$ & $b_{1}$ & $\mathrm{C}_{2}$ & $d_{3}$ & $\mathrm{e}_{4}$ & $f_{5}$ & 5 & 5 & 4,01 & 4,32 & 37,60 & 35,60 & 0,85 & 0,77 & 11,4 & 12,2 \\
\hline 7 & $a_{2}$ & $b_{2}$ & $\mathrm{C}_{3}$ & $d_{4}$ & $e_{5}$ & $f_{1}$ & 5 & 5 & 0,53 & 0,62 & 74,66 & 74,50 & 0,08 & 0,05 & 29,5 & 30,1 \\
\hline 8 & $a_{2}$ & $b_{3}$ & $\mathrm{C}_{4}$ & $d_{5}$ & $e_{1}$ & $f_{2}$ & 4 & 4 & 3,83 & 3,73 & 37,66 & 40,66 & 6,55 & 5,45 & 24,4 & 25,2 \\
\hline 9 & $a_{2}$ & $b_{4}$ & $\mathrm{C}_{5}$ & $\mathrm{~d}_{1}$ & $\mathrm{e}_{2}$ & $f_{3}$ & 4 & 4 & 4,42 & 4,21 & 20,66 & 23,33 & 3,1 & 2,88 & 19,3 & 20,1 \\
\hline 10 & $a_{2}$ & $b_{5}$ & $\mathrm{C}_{1}$ & $\mathrm{~d}_{2}$ & $\mathrm{e}_{3}$ & $f_{4}$ & 5 & 4 & 4,38 & 4,36 & 64,33 & 66,00 & 1,55 & 1,21 & 7,3 & 8,3 \\
\hline 11 & $a_{3}$ & $b_{1}$ & $\mathrm{C}_{3}$ & $d_{5}$ & $\mathrm{e}_{2}$ & $f_{4}$ & 4 & 3 & 1,20 & 1,63 & 32,66 & 27,66 & 1,10 & 0,98 & 12,4 & 13,2 \\
\hline 12 & $a_{3}$ & $b_{2}$ & $\mathrm{C}_{4}$ & $\mathrm{~d}_{1}$ & $\mathrm{e}_{3}$ & $f_{5}$ & 3 & 4 & 4,36 & 4,50 & 27,66 & 26,30 & 1,44 & 1,23 & 12,1 & 12,4 \\
\hline 13 & $a_{3}$ & $b_{3}$ & $\mathrm{C}_{5}$ & $d_{2}$ & $\mathrm{e}_{4}$ & $f_{1}$ & 3 & 4 & 4,47 & 4,87 & 93,00 & 86,00 & 0,11 & 0,08 & 9,3 & 10,2 \\
\hline 14 & $a_{3}$ & $\mathrm{~b}_{4}$ & $\mathrm{C} 1$ & $d_{3}$ & $\mathrm{e}_{5}$ & $f_{2}$ & 4 & 4 & 3,82 & 3,64 & 27,33 & 30,66 & 11,4 & 10,34 & 9,4 & 10,1 \\
\hline 15 & $a_{3}$ & $b_{5}$ & $\mathrm{C}_{2}$ & $\mathrm{~d}_{4}$ & $\mathrm{e}_{1}$ & $f_{3}$ & 5 & 5 & 3,06 & 2,17 & 39,30 & 41,33 & 8,02 & 7,88 & 13,4 & 14,0 \\
\hline 16 & $a_{4}$ & $b_{1}$ & $\mathrm{C}_{4}$ & $d_{2}$ & $\mathrm{e}_{5}$ & $f_{3}$ & 4 & 5 & 4,92 & 4,28 & 27,33 & 26,99 & 2,33 & 1,98 & 14,4 & 14,1 \\
\hline 17 & $a_{4}$ & $b_{2}$ & $\mathrm{C}_{5}$ & $\mathrm{~d}_{3}$ & $e_{1}$ & $f_{4}$ & 4 & 5 & 4,89 & 4,62 & 47,66 & 42,00 & 12,23 & 10,32 & 28,1 & 29,5 \\
\hline 18 & $a_{4}$ & $b_{3}$ & $c_{1}$ & $\mathrm{~d}_{4}$ & $\mathrm{e}_{2}$ & $f_{5}$ & 4 & 5 & 1,96 & 2,60 & 62,00 & 66,66 & 0,92 & 0,81 & 14,0 & 14,4 \\
\hline 19 & $a_{4}$ & $b_{4}$ & $\mathrm{C}_{2}$ & $d_{5}$ & $\mathrm{e}_{3}$ & $f_{1}$ & 5 & 5 & 2,05 & 1,98 & 64,60 & 66,33 & 5,88 & 4,88 & 30,1 & 31,2 \\
\hline 20 & $a_{4}$ & $b_{5}$ & $\mathrm{C}_{3}$ & $\mathrm{~d}_{1}$ & $\mathrm{e}_{4}$ & $f_{2}$ & 4 & 4 & 3,29 & 1,83 & 56,60 & 55,33 & 0,92 & 0,87 & 33,5 & 34,6 \\
\hline 21 & $a_{5}$ & $b_{1}$ & $\mathrm{C}_{5}$ & $\mathrm{~d}_{4}$ & $\mathrm{e}_{3}$ & $f_{2}$ & 3 & 4 & 3,82 & 3,18 & 21,99 & 22,30 & 9,21 & 8,34 & 14,4 & 14,5 \\
\hline 22 & $a_{5}$ & $b_{2}$ & $\mathrm{C}_{1}$ & $d_{5}$ & $\mathrm{e}_{4}$ & $f_{3}$ & 5 & 5 & 4,27 & 4,16 & 67,96 & 70,60 & 0,13 & 0,22 & 12,5 & 13,1 \\
\hline 23 & $a_{5}$ & $b_{3}$ & $\mathrm{C}_{2}$ & $\mathrm{~d}_{1}$ & $e_{5}$ & $f_{4}$ & 4 & 5 & 2,01 & 1,18 & 44,60 & 46,30 & 0,14 & 0,25 & 33,1 & 34,4 \\
\hline 24 & $a_{5}$ & $b_{4}$ & $\mathrm{C}_{3}$ & $\mathrm{~d}_{2}$ & $e_{1}$ & $f_{5}$ & 4 & 4 & 4,85 & 1,74 & 46,00 & 47,60 & 7,88 & 6,45 & 8,1 & 9,1 \\
\hline 25 & $a_{5}$ & $b_{5}$ & $\mathrm{C}_{4}$ & $d_{3}$ & $\mathrm{e}_{2}$ & $f_{1}$ & 5 & 5 & 2,45 & 2,32 & 36,66 & 39,00 & 6,55 & 5,45 & 14,1 & 16,0 \\
\hline
\end{tabular}

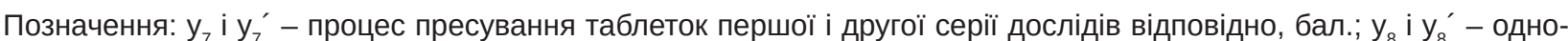
рідність маси таблеток першої і другої серії дослідів відповідно, \pm \%; $y_{9}$ і у у - стійкість таблеток до роздавлювання

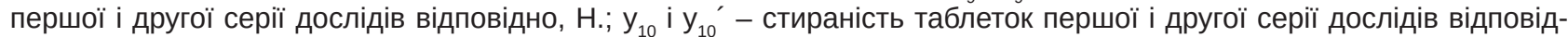
но, \%; у $_{11}$ і у ${ }_{11}^{\prime}$ - час розпадання таблеток першої і другої серії дослідів відповідно, хв.

ISSN 2312-0967. Фармацевтичний часопис. 2018. № 1 
Фармацевтична технологія, біофармація, гомеопатія

Pharmaceutical technology, biopharmacy, homeopathy

фрактор A -наповнювачі на основі цукрів $\left(\mathrm{a}_{1}\right.$ - таблетоза, $\mathrm{a}_{2}$ - лудіпрес, $\mathrm{a}_{3}-$ маніт, $\mathrm{a}_{4}-$ цукор компрі $\mathrm{O}, \mathrm{a}_{5}$ - парлітол 100SD+манітол), фрактор В - ДР різних зразків МКЦ (b - МКЦ 102, $b_{2}-$ МКЦ 12, $b_{3}-$ МКЦ 200 , $\mathrm{b}_{4}$ - МКЦ 112, $\mathrm{b}_{5}-$ МКЦ 302), фрактор $\mathrm{C}$ - ковзні речовини (регулятори вологи) ( $\mathrm{c}_{1}-$ кальцій карбонат, $\mathrm{c}_{2}$ неусилін УФЛ, с $\mathrm{c}_{3}$ - неусилін УС 2, с 4 - магній карбонат основний, $\mathrm{c}_{5}$ - тальк), фрактор $\mathrm{D}$ - розпушуючі $\left(\mathrm{d}_{1}-\right.$ кросповідон ХЛ-10, $\mathrm{d}_{2}$ - натрій кроскармелоза, $\mathrm{d}_{3}$ натрій крохмальгліколят, $\mathrm{d}_{4}$ - натрій карбоксиметилкрохмаль, $\mathrm{d}_{5}$ - крохмаль преджелетинізований), фрактор $\mathrm{E}$ - наповнювачі на основі комбінацій похідних целюлози і МКЦ 3 іншими ДР (е (МКЦ+аеросил), е 2 - просолв ОДТ Г 2 (МКЦ + аеросил + манітол+орруктоза+кросповідон), е e $_{3}$ МКЦ+натрій КМЦ, е 4 - МКЦ бурст, е табл. (похідні целюлози+дикальцій фросфрат), фрактор $\mathrm{F}$ - змащувальні речовини $\left(\mathrm{f}_{1}-\right.$ магнію стеарат, $\mathrm{f}_{2}-$ кальцію стеарат, $\mathrm{f}_{3}$ - кислота стеаринова, $\mathrm{f}_{4}$ - олія гідрогенізована (лубрітаб), $\mathrm{f}_{5}$ - натрію стеарилфрумарат).

Таблетки екстракту чорниці листя, екстракту козлятника трави і таурину отримували методом прямого пресування. Для вивчення 6-ти якісних фракторів використовували гіпер-греко-латинський квадрат четвертого порядку [9]. Матриця планування експерименту та результати дослідження таблеток екстракту чорниці листя, екстракту козлятника трави і таурину наведено в таблиці 1. Позначення відгуків наводили з врахуванням інорормації, яка наведена в повідомленні 1 [7].

Результати й обговорення. Досліди були реалізовані у двох повторностях, що дозволило зменшити помилку експерименту та отримати інорормацію про можливу взаємодію між рівнями вивчених фракторів. Оцінку процесу пресування таблеток екстракту чорниці листя, екстракту козлятника трави і таурину проводили за п'ятибальною шкалою. Отримані таблетки досліджували на однорідність маси, стійкість таблеток до роздавлювання, стираність та час розпадання згідно з вимогами ДФУ 2 [10].

За результатами досліджень проводили дисперсійний аналіз експериментальних даних, порівнювали вплив рівнів значущих фракторів та робили висновки.

При створенні таблеток методом прямого пресування важливим моментом є стадія пресування. При цьому таблетки можуть прилипати до матриці і пуансонів. Поверхня зпресованих таблеток може мати різний відтінок (блискучість, рельєфнність тощо). Характеристики процесу пресування таблеток екстракту чорниці листя, екстракту козлятника трави і таурину оцінювали за 5-бальною системою: здатність маси для таблетування до прилипання, силу виштовхування таблеток та якість їх поверхні $\left(\mathrm{y}_{7}\right)$.

Дисперсійний аналіз експериментальних даних показав, що вплив вивчених якісних фракторів на процес пресування таблеток екстракту чорниці листя, екстракту козлятника трави і таурину має наступний вигляд: $\mathrm{A}>\mathrm{F}>\mathrm{C}=\mathrm{D}$ при статистичній незначущості фракторів В і Е.

Вплив природи цукрів на процес пресування таблеток екстракту трави козлятника, екстракту листя чорниці та таурину зображено на рисунку 1.

Аналіз рисунка 1 показав, що найкраще процес пресування таблеток екстракту чорниці листя, екс-

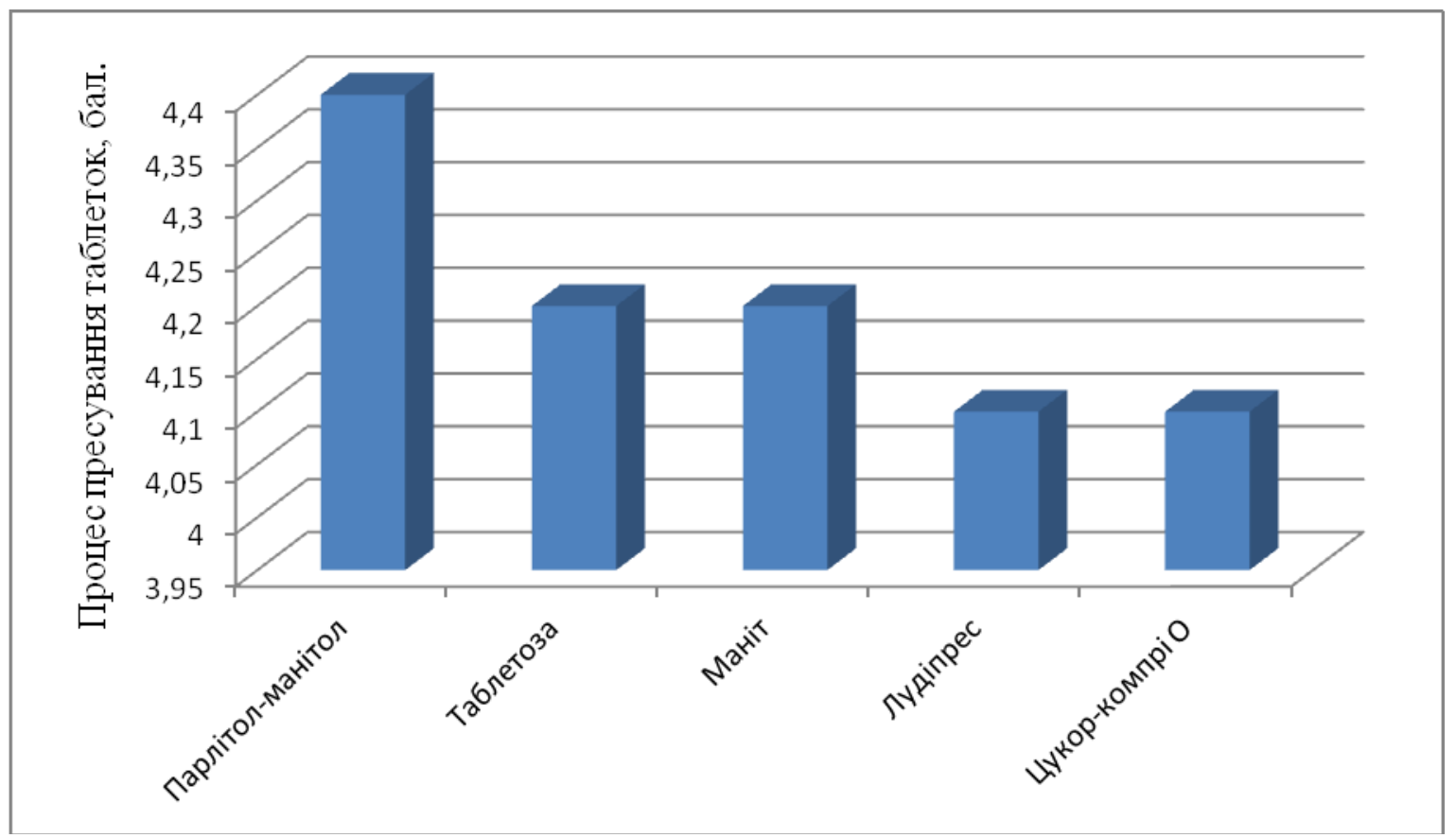

Рис. 1. Вплив природи цукрів на процес пресування таблеток екстракту чорниці листя, екстракту козлятника трави і таурину.

ISSN 2312-0967. Pharmaceutical review. 2018. № 1 
Фармацевтична технологія, біофармація, гомеопатія Pharmaceutical technology, biopharmacy, homeopathy

тракту козлятника трави і таурину проходить при використанні - парлітол 100SD+манітолу (4,4 бал.). Ця суміш має перевагу над таблетозою (4,2 бал.), манітом (4,2 бал.), лудіпресом (4,1 бал.) та цукром компрі O (4,1 бал.).

Подібним чином будували діаграми для інших значущих фракторів. Серед вивчених змащувальних речовин найкраще процес пресування таблеток екстракту чорниці листя, екстракту козлятника трави і таурину проходив при використанні кислоти стеаринової (4,6 бал.), яка має перевагу над магнію стеаратом (4,4 бал.), натрію стеарилфумаратом (4,2 бал.), олією гідрогенізованою (4,0 бал.) та кальцію стеаратом (3,8 бал.).

Ранжований ряд переваг для вивчених ковзних речовин на процес пресування таблеток екстракту чорниці листя, екстракту козлятника трави і таурину має наступний вигляд: неусилін УФЛ (4,6 бал.) > кальцій карбонат (4,3 бал.) > неусилін УС (4,2 бал.) > магній карбонат основний (4,0 бал.) > тальк (3,9 бал.).

Встановлено, що найкраще процес пресування таблеток екстракту чорниці листя, екстракту козлятника трави і таурину проходить при використанні натрій крохмальгліколяту (4,6 бал.), який має перевагу над крохмалем преджелетинізованим (4,3 бал.), натрій карбоксиметилкрохмалем (4,2 бал.), натрій кроскармелозою (4,0 бал.) та кросповідоном ХЛ 10 (3,9 бал.)

При створенні таблеток, що містять багатокомпонентну суміш із трьох активних орармацевтичних інгредієнтів (АФІ) та шести груп ДР важливим показником виступає однорідність маси спресованих таблеток. Різні розміри та фоорми АФІ і ДР можуть приводи- ти до сепарації деяких дрібнодисперсних компонентів в процесі роботи таблеткової машини.

Вплив вивчених якісних фракторів на однорідність маси таблеток екстракту чорниці листя, екстракту козлятника трави і таурину відображає наступний ряд: C > D > E > F при статистичній незначущості фракторів A і B.

Вплив ковзних речовин на однорідність маси таблеток екстракту чорниці листя, екстракту козлятника трави і таурину наведено на рисунку 2.

Як видно з даних рисунка 2, найбільш однорідна маса таблеток екстракту чорниці листя, екстракту козлятника трави і таурину отримана при використанні неусіліну УС $2( \pm 2,12 \%)$ та неусиліну УФЛ $( \pm 2,5 \%)$, які мають перевагу над магнію карбонатом основним ( $\pm 3,52 \%)$, кальцію карбонатом (3,78 \%) та тальком $( \pm 3,99 \%)$.

Ранжований ряд переваг для вивчених розпушувачів за впливом на однорідність маси таблеток екстракту чорниці листя, екстракту козлятника трави і таурину має наступний вигляд: натрій карбоксиметилкрохмаль $( \pm 2,28 \%)>$ крохмаль преджелетинізований $( \pm 2,8 \%)>$ кросповідон ХЛ $10( \pm 3,42 \%)>$ натрій крохмальгліколят $( \pm 3,56 \%)>$ натрій кроскармелоза $( \pm 3,83 \%)$.

Найкраща однорідність маси таблеток екстракту чорниці листя, екстракту козлятника трави і таурину спостерігається при використанні в якості ДР просолву ОДЕ Г 2 ( $\pm 2,53 \%)$ та гарке плюс табл. $( \pm 2,65 \%)$. Вказані ДР мають перевагу над МКЦ бурст ( $\pm 3,42 \%)$, просолвом 90 ( $\pm 3,61 \%)$ та сумішшю МКЦ+натрій КМЦ $( \pm 3,74 \%)$

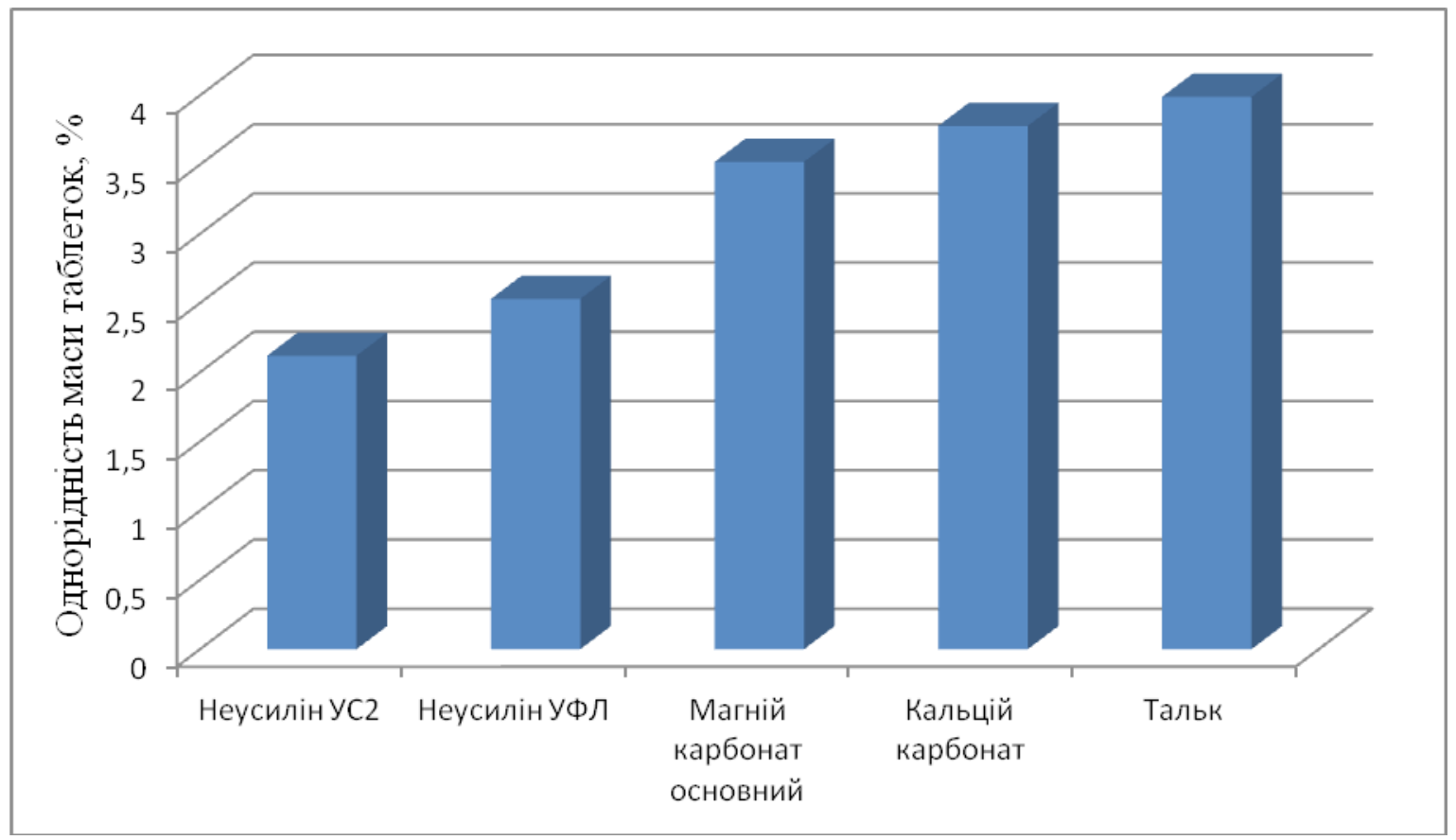

Рис. 2. Вплив ковзних речовин на однорідність маси таблеток екстракту чорниці листя, екстракту козлятника трави і таурину.

ISSN 2312-0967. Фармацевтичний часопис. 2018. № 1 
Встановлено, що найбільш однорідна маса таблеток екстракту чорниці листя, екстракту козлятника трави і таурину отримана при використанні в якості змазуючої речовини магнію стеарату ( $\pm 2,53 \%)$ та олії гідрогенізованої ( $\pm 2,65$ \%). Вказані ДР мають суттєву перевагу над кальцію стеаратом $( \pm 3,425)$, натрію стеарилфумаратом ( $\pm 3,61 \%)$ та кислотою стеариновою $( \pm 3,74$ \%). Зазначимо, що середнє значення однорідності маси таблеток екстракту чорниці листя, екстракту козлятника трави і таурину не перевищувало фрармакопейні норми $( \pm 5,00)$.

Стійкість до роздавлювання найбільше характеризує пресованість порошкового матеріалу. Традиційно сухі екстракти мають погану пресованість, тому досягти позитивного результату можливо за рахунок використання ДР з доброю пластичністю до деформації.

Вивчені якісні фрактори впливають на стійкість таблеток екстракту чорниці листя, екстракту козлятника трави і таурину до роздавлювання наступним чином: $\mathrm{B}>\mathrm{E}>\mathrm{F}>\mathrm{C}>\mathrm{D}>\mathrm{F}$.

Вплив різних зразків МКЦ на стійкість таблеток екстракту чорниці листя, екстракту козлятника трави і таурину до роздавлювання зображено на рисунку 3.

На підставі аналізу даних рисунка 3 ранжований ряд переваг щодо впливу зразків МКЦ на стійкість таблеток екстракту чорниці листя, екстракту козлятника трави і таурину до роздавлювання має наступний вигляд: МКЦ $200(63,62$ Н) > МКЦ $12(48,7$ Н) > МКЦ $112(45,15$ Н) > МКЦ $02(43,78$ Н) > МКЦ $102(29,11$ Н). Зазначимо, що широковживана для виробництва таблеток методом прямого пресування МКЦ 102 зай-
Фармацевтична технологія, біофармація, гомеопатія

Pharmaceutical technology, biopharmacy, homeopathy

має останнє місце і стійкість таблеток до роздавлювання з її використанням вдвічі менша, ніж при використанні МКЦ 200.

Найбільш стійкі до роздавлювання таблетки екстракту чорниці листя, екстракту козлятника трави і таурину отримували при використанні МКЦ бурст $(62,77 \mathrm{H})$, яка має перевагу над МКЦ+натрій КМЦ $(51,64 \mathrm{H})$, просолвом $90(40,11 \mathrm{H})$, гарке плюс табл. $(39,14$ H) та просолвом ОДТ Г 2 (36,49 H).

Найбільш стйкими до роздавлювання отримували таблетки екстракту чорниці листя, екстракту козлятника трави і таурину при використанні в якості змазуючої речовини магнію стеарату $(59,41 \mathrm{H})$, який має перевагу над олією гідрогенізованою $(49,62$ Н), кислотою стеариновою $(47,68$ H), натрію стеарилфумаратом $(38,84 \%)$ та кальцію стеаратом $(29,14 \mathrm{H})$.

Ранжований ряд переваг ковзних речовин за впливом на стійкість таблеток екстракту чорниці листя, екстракту козлятника трави і таурину до роздавлювання має наступний вигляд: неусилін УС $2(57,43 \mathrm{H})$ $>$ кальцію карбонат $(51,48$ H) > неусилін УФЛ $(43,16$ H) $>$ магній карбонат основний $(39,60$ H) > кальцію карбонат $(38,72 \mathrm{H})$.

Найбільш стійкі до роздавлювання таблетки екстракту чорниці листя, екстракту козлятника трави і таурину отримували при використанні натрію кроскармелози (51,32 Н) та натрій карбоксиметилкрохмалю $(52,78$ Н), які мають перевагу над натрій крохмальгліколятом $(45,58$ H), крохмалем преджелетенізованим (44,72 Н) та кросповідоном ХЛ 10 (36,01 Н).

Стираність таблеток, що отримують прямим пресуванням, теж є суттєвим показником, який характе-

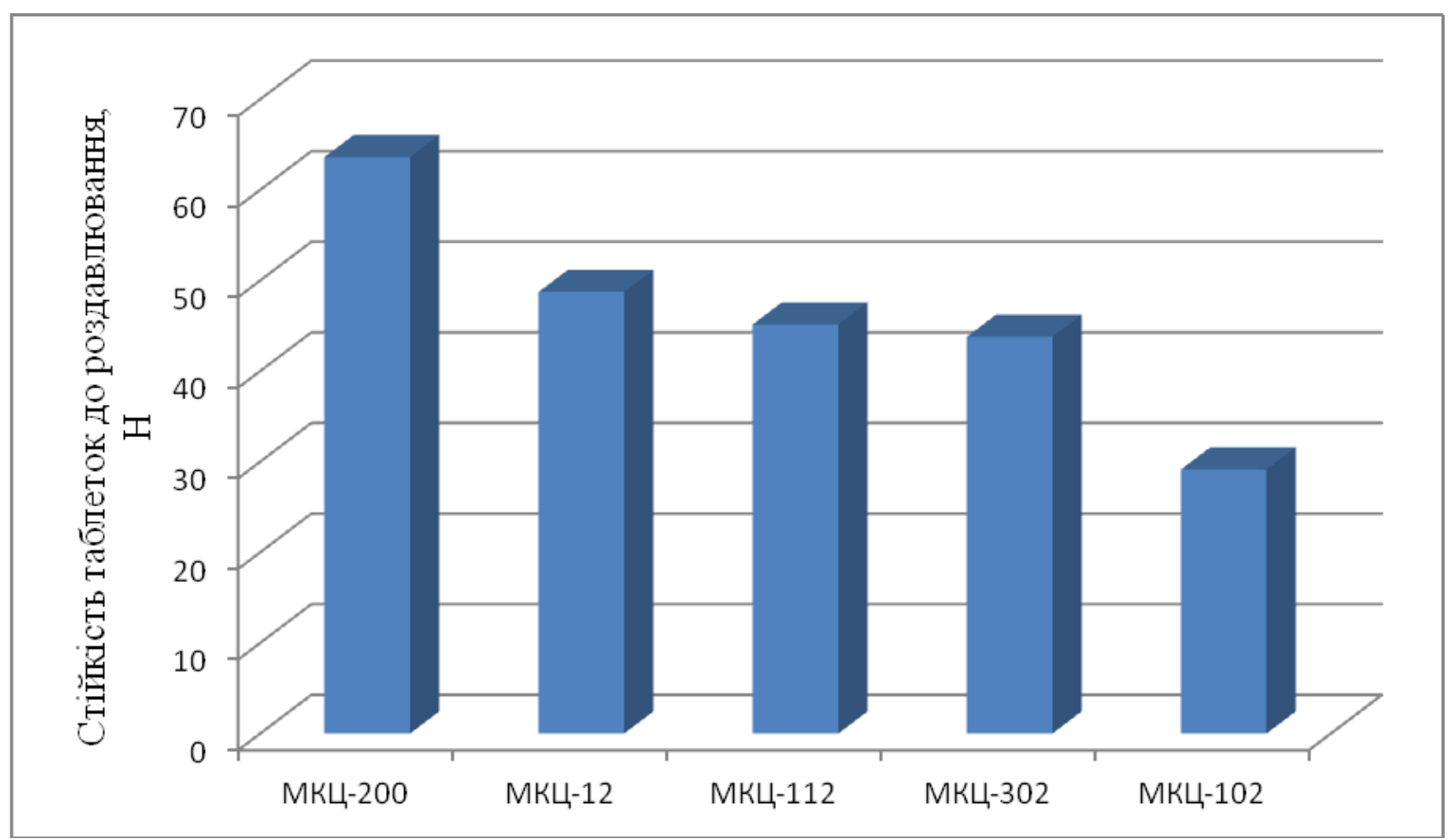

Рис. 3. Вплив різних зразків МКЦ на стійкість таблеток екстракту чорниці листя, екстракту козлятника трави і таурину до роздавлювання.

ISSN 2312-0967. Pharmaceutical review. 2018. № 1 
Фармацевтична технологія, біофармація, гомеопатія Pharmaceutical technology, biopharmacy, homeopathy

ризує здатність порошкової маси до пластичної деформації. Результати первинних досліджень показали, що у більшості серій дослідів стираність таблеток екстракту чорниці листя, екстракту козлятника трави і таурину була суттєвою і перевишувала фрармакопейну норму - $1 \%$.

Вплив вивчених фракторів на стираність екстракту чорниці листя, екстракту козлятника трави і таурину можна зобразити наступним рядом переваг: $\mathrm{E}>\mathrm{C}>$ $\mathrm{B}>\mathrm{D}>\mathrm{F}>\mathrm{A}$.

Вплив модифрікованих зразків МКЦ на стираність таблеток екстракту чорниці листя, екстракту козлятника трави і таурину зображено на рисунку 4.

Як видно з даних рисунка 4, найменшу стираність мали таблетки екстракту чорниці листя, екстракту козлятника трави і таурину, до складу яких входила МКЦ бурст (0,46 \%). Цій ДР поступаються просолв ОДТ Г2 (2,34 \%), МКЦ+натрій КМЦ (3,43\%), гарке плюс табл. (4,68 \%) і просолв 90 (7,98 \%).

Найменша стираність таблеток екстракту чорниці листя, екстракту козлятника трави і таурину спостерігається при використанні неусиліну УС 2 (1,89\%), який має перевагу над неусиліном УФЛ (3,01 \%), магнію карбонатом основним (3,1 $6 \%)$, кальцію карбонатом $(3,46 \%)$ і тальком $(6,65 \%)$.

Ранжований ряд переваг зразків МКЦ на стираність таблеток екстракту чорниці листя, екстракту козлятника трави і таурину має наступний вигляд: МКЦ 200 (1,48\%), МКЦ 12 (2,73\%), МКЦ 102(3,38 \%), МКЦ 302 (5,27 \%), МКЦ 112 (5,34 \%).

Найменша стираність таблеток екстракту чорниці листя, екстракту козлятника трави і таурину спосте- рігається при використанні кросповідону ХЛ 10 $(1,88 \%)$, який має перевагу над натрій кроскармелозою (2,32 \%) натрій карбоксиметилкрохмалем (3,59 \%), крохмалем преджелетенізованим (4,55 \%) і натрій крохмальгліколятом (5,84 \%).

Найменша стираність таблеток екстракту чорниці листя, екстракту козлятника трави і таурину спостерігається при використанні кислоти стеаринової $(2,71 \%)$ та олії гідрогенізованої (2,84 \%). Вказані ДР мають перевагу над магнію стеаратом (3,11 \%), натрію стеарилорумаратом (4,08 \%) та кальцію стеаратом $(5,77 \%)$.

Найменша стираність таблеток екстракту чорниці листя, екстракту козлятника трави і таурину отримана при використанні лудіпресу (2,24 \%), який має перевагу над таблетозою (3,12 \%), цукром компрі О $(4,14 \%)$, манітолом $(4,29 \%)$ та парлітол $100 \mathrm{SD}+$ манітолом $(4,46 \%)$.

При створенні таблеток екстракту чорниці листя, екстракту козлятника трави і таурину час розпадання виявився одним із найбільш суттєвих показників. Великі розміри таблеток екстракту чорниці листя, екстракту козлятника трави і таурину й відповідно середня маса впливають на час розпадання спресованих таблеток. Вплив вивчених якісних фракторів на час розпадання таблеток екстракту чорниці листя, екстракту козлятника трави і таурину відображає наступний ряд переваг: A > D > C > F > B > E.

Вплив природи цукрів на час розпадання таблеток чорниці зображено на рисунку 5.

3 даних рисунка 5 видно, що при використанні маніту (11,6 хв) та таблетози (14,1 хв) отримані таблетки

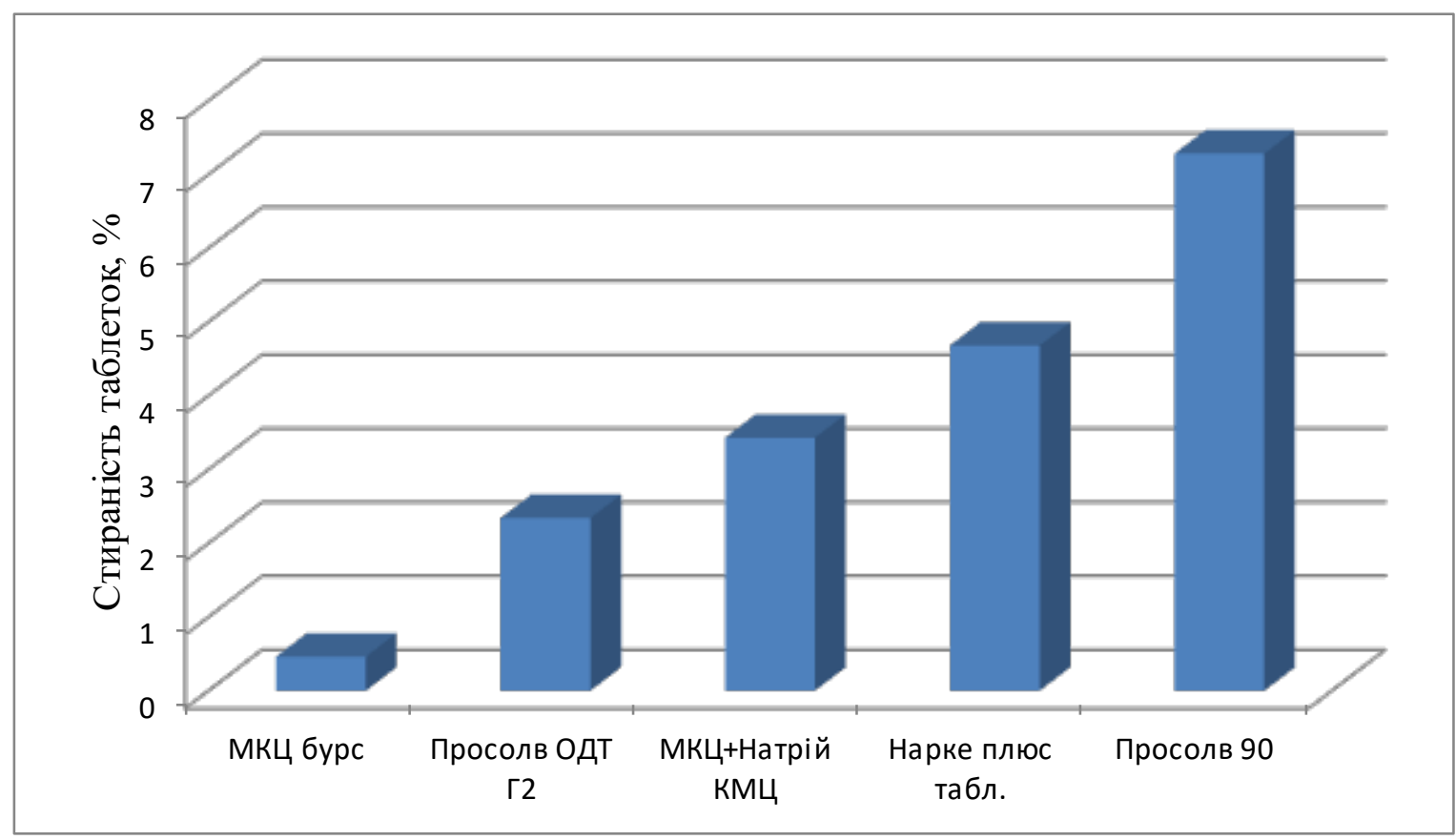

Рис. 4. Вплив модифікованих зразків МКЦ на стираність таблеток екстракту чорниці листя, екстракту козлятника трави і таурину.

ISSN 2312-0967. Фармацевтичний часопис. 2018. № 1 
Фармацевтична технологія, біофармація, гомеопатія Pharmaceutical technology, biopharmacy, homeopathy

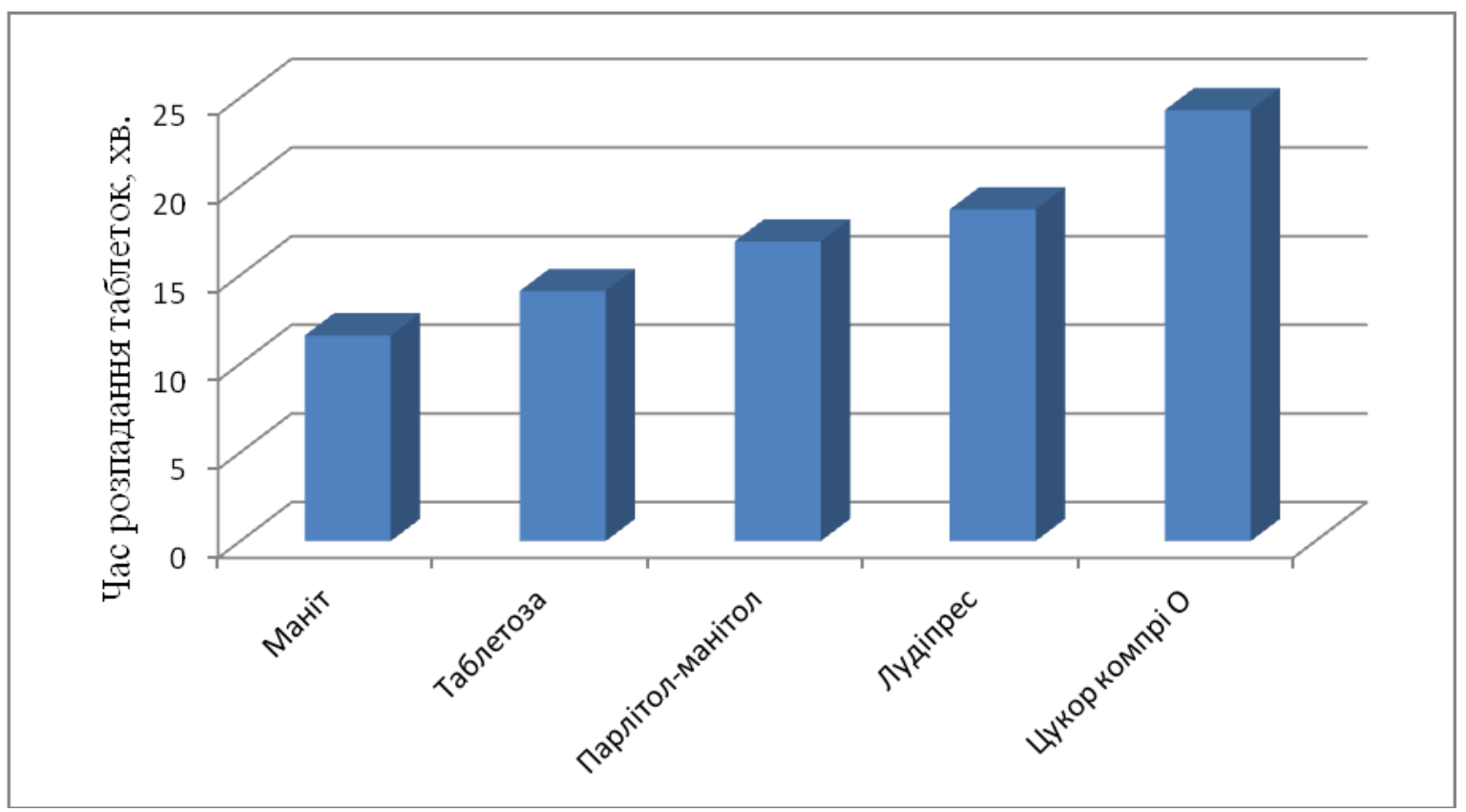

Рис. 5. Вплив природи цукрів на час розпадання таблеток екстракту чорниці листя, екстракту козлятника трави і таурину.

екстракту чорниці листя, екстракту козлятника трави і таурину відповідали вимогам фрармакопеї. Використання парлітол 100SD+манітолу (16,9 хв), лудіпресу (18,7 хв) та цукру компрі О (24,3 хв) веде до сповільнення часу розпадання таблеток екстракту чорниці листя, екстракту козлятника трави і таурину.

Найбільш есективною розпушуючою речовиною виявилась натрій кроскармелоза (9,8 хв), яка має суттєву перевагу над натрій крохмальгліколятом (16,8 хв), натрій карбоксиметилкрохмалем (17,7 хв), крохмалем преджелетенізованим $(18,7$ хв) та кросповідоном ХЛ 10 (22,5 хв).

Найшвидше розпадалися таблетки екстракту чорниці листя, екстракту козлятника трави і таурину, до складу яких входить кальцію карбонат (11,6 хв). Вказана ДР має переваги над магнію карбонатом основним (16,6 хв), тальком (17,1 хв), неусиліном УФЛ (19,7 Хв) і неусиліном УС 2 (20,8 Хв).

Серед вивчених змащующих речовин найменший час розпадання таблеток екстракту чорниці листя, екстракту козлятника трави і таурину отримували при використанні натрій стеарилорумарату (11,9 хв). Вказана ДР має переваги над кислотою стеариновою (15,8 хв), кальцію стеаратом (18,3 хв), магнію стеаратом (19,7 хв) та олією гідрогенізованою (19,9 хв).

Найшвидше розпадаються таблетки екстракту чорниці листя, екстракту козлятника трави і таурину які містять в складі МКЦ 102 (13,4 хв). МКЦ 102 має переваги над МКЦ 302 (16,7 хв), МКЦ 112 (17,0 хв), МКЦ 12 (18,4 хв) та МКЦ 200 (20,2 хв).

Ранжований ряд переваг для наведеного рисунка дозволяє розмістити вивчені ДР в наступній послідовності: просолв ОДТ Г 2 (14,0хв.), МКЦ+натрій
КМЦ (16,7 хв), МКЦ бурст (17,0 хв), просолв 90 (17,9 хв), гарке плюс табл. (20,0 хв.).

При виборі кращих ДР враховували результати досліджень, які отримували при оцінці технологічних властивостей порошкових мас для таблетування, які наведені в повідомленні 1 [7] за відгуками (показниками) $\mathrm{y}_{7}-\mathrm{y}_{11}$. Для цього будували ряди переваг (лідерів) за кожним із значущих фракторів за процедурою, яка описана в монографрії з використанням суми місць рівнів вивчених якісних фракторів [8]. При цьому чим менша сума місць, яку займає рівень вивченого фактора, тим ефективніший він за впливом на сумарний показник.

На підставі отриманих балів, із вивчених якісних фракторів, будували ряди переваг. Так, серед вивчених наповнювачів на основі цукрів (фрактор А) отримали наступний ряд переваг: маніт -10 балів, таблетоза -13 балів, лудіпрес -17 балів, цукор компрі О 17 балів і парлітол-манітол - 17 балів. Для наступних експериментальних досліджень 3 метою отримання таблеток рекомендовано маніт та таблетозу.

Серед вивчених зразків МКЦ (фактор В) отримали наступний ряд переваг: МКЦ 200 -9 балів, МКЦ 12 9 балів, МКЦ 302 - 12 балів, МКЦ 112 -17 балів, і МКЦ 102 - 19 балів. Зазначимо, що МКЦ 102, яка найчастіше використовується при створенні таблеток методом прямого пресування, в рейтинговому ряду займає останнє місце на фроні нових ДР з ряду МКЦ, що виводяться на ринок. Для подальших досліджень із створення таблеток відібрано МКЦ 200, яка в рейтинговому ряду займає одне із перших місць за показником стираності та стійкості таблеток до роздавлювання, однак останнє місце за впливом на час розпадан-

ISSN 2312-0967. Pharmaceutical review. 2018. № 1 
Фармацевтична технологія, біофармація, гомеопатія Pharmaceutical technology, biopharmacy, homeopathy

ня таблеток екстракту чорниці листя, екстракту козлятника трави і таурину.

Серед ковзких речовин (фрактор С) отримали наступний ряд переваг: неусилін УС 2 - 16 балів, кальцію карбонат - 17 балів, магнію карбонат основний - 19 балів, неусилін УФЛ -19 балів і тальк - 29 балів. Зазначимо, що тальк, який часто використовують у виробництві таблеток на фоні нових ДР, займає останнє місце. Для подальших експериментальних досліджень використали неусилін УС 2 та кальцію карбонат.

Вивчені розпушувачі (фактор D) дозволили побудувати наступний ряд переваг: натрій карбоксиметилкрохмаль - 12 балів, натрій кроскармелоза - 19 балів, крохмаль преджелетинізований - 21 бал, натрій крохмальгліколят -23 бали і кросповідон ХЛ 10 - 26 балів. Для подальших досліжень відібрані натрій карбоксиметилкрохмаль і натрій кроскармелоза.

Структуроутворюючі речовини на основі комбінацій МКЦ $з$ іншими ДР (фактор Е) можна розмістити в наступний ряд переваг: просолв ОДТ г 2 - 11 балів, МКЦ бурст - 12 балів, МКЦ+натрій КМЦ - 13 балів, гарке плюс табл.- 15 балів і просолв 90 - 19 балів. Для подальших досліджень відібрано просолв ОДЕ Г 2.

Змазуючі речовини (фактор F) дають наступний ряд переваг: магнію стеарат - 14 балів, кислота сте- аринова - 16 балів, олія гідрогенізована - 21 бал, натрію стеарилсумарат - 26 балів і кальцію стеарат 28 балів. Для подальших експериментальних досліджень відібраний магнію стеарат. Натрію стеарилсрумарат раціонально використовувати з метою прискорення часу розпадання таблеток, а олію рафріновану - для пролонгації дії.

Висновки. 1. Вивчено вплив 30-ти допоміжних речовин на фрармако-технологічні властивості таблеток (процес пресування, однорідність маси, стійкість до роздавлювання, стираність, розпадання) екстракту чорниці листя, екстракту козлятника трави і таурину, які отримували методом прямого пресування.

2. За допомогою шестифракторного експерименту - гіпер-греко-латинського квадрату четвертого порядку вивчено вплив 6-ти якісних фракторів на основні відгуки (показники) таблеток екстракту чорниці листя, екстракту козлятника трави і таурину.

3. Для подальших експериментальних досліджень із створення оптимального складу і технології таблеток екстракту чорниці листя, екстракту козлятника трави і таурину рекомендовано дослідити маніт, таблетозу, МКЦ 200, неусилін УС 2, кальцію карбонат, натрій карбоксиметилкрохмаль, натрій кроскармелозу, просолв ОДТ г 2 і магнію стеарат.

\title{
ИЗУЧЕНИЕ ВЛИЯНИЯ ВСПОМОГАТЕЛЬНЫХ ВЕЩЕСТВ НА ФАРМАКО-ТЕХНОЛОГИЧЕСКИЕ СВОЙСТВА ТАБЛЕТОК ЭКСТРАКТА ЧЕРНИКИ ЛИСТЬЯ, ЭКСТРАКТА КОЗЛЯТНИКА ТРАВЫ И ТАУРИНА, ПОЛУЧЕННЫХ МЕТОДОМ ПРЯМОГО ПРЕССОВАНИЯ
}

\author{
О. 3. Барчук¹, Т. А. Грошовый², О. Н. Залиская ${ }^{1}$, В. Я. Шалата ${ }^{3}$
}

Львовский национальный медицинский университет имени Данила Галицкого ${ }^{1}$ ГВУз «Тернопольский государственный медицинский университет имени И. Я. Горбачевского МЗ Украины»² ПАТ «Галичфрарм» ${ }^{3}$

olvia2003@ukr.net

Цель роботи. Исследование влияния вспомогательных веществ на фрармако-технологические свойства таблеток 3 целью разработки нового комбинированного лекарственного средства с гипогликемической активностью на основе сухих экстрактов черники листья, козлятника травы и таурина методом прямого прессования.

Материалы и методы. Основные действующие вещества - сухие экстракты листья черники обыкновенной, травы козлятника лекарственного и таурина, а также 30 вспомогательных веществ. Исследование влияния вспомогательных вещества (BВ) на фрармако-технологические показатели (процесс прессования, однородность массы, устойчивость таблеток к раздавливанию, стираемость и время распада ) при разработке таблеток экстракта черники листья, экстракта козлятника травы и таурина проводили в соответствии с требованиями ГФУ 2.

Результаты и обсуждение. Изучено влияние 30-ти ВВ на фрармако-технологические показатели таблеток (процесс прессования, однородность массы, устойчивость таблеток к раздавливанию, стираемость и время распада) экстракта черники листья, экстракта козлятника травы и таурина. Дисперсионный анализ полученных результатов показал, что лучше всего процесс прессования таблеток экстракта черники листья, экстракта козлятника травы и таурина проходит при использовании смеси парлитол 100 SD+маннитола, кислоты стеариновой, неусилина УФЛ и натрий крахмалгликолята. Найболие однородная масса таблеток полученна при использовании неусилина Ус 2 и неусилина УФЛ, натрий карбоксиметилкрахмала, просолва ОДТ Г 2, магния стеарата и масла гидрогенизированного.

Наиболее устойчивы к раздавливанию таблетки экстракта черники листья, экстракта козлятника травы и таурина получали при использовании МКЦ 200, МКЦ бурст, магния стеарата, неусилина УС 2, натрия кроскармелозы и натрия карбоксиметилкрахмала.

ISSN 2312-0967. Фармацевтичний часопис. 2018. № 1 
Наименьшую стираемость имели исследуемые таблетки, в состав которых входила МкЦ бурст, неусилин Ус 2 , МКЦ 200, кросповидон ХЛ 10, стеариновая кислота и лудипрес.

Быстрее всего распадались таблетки экстракта черники листья, экстракта козлятника травы и таурина при использовании маннита, таблетозы, натрий кроскармелозы, кальция карбоната, натрий стеарилфумарата, Мкц 102, просолва ОДТ г 2.

Полученные результаты исследований по фрармако-технологическим показателям таблеток экстракта черники листья, экстракта козлятника травы и таурина указывают на рациональность более детального исследования в их составе количества маннита, таблетозы, МКЦ 200, неусилина УС 2, натрия карбоксиметилкрахмала, натрий кроскармелозы, просолва ОДт г 2 и магния стеарата.

Выводы. Изучено влияние 30-ти ВВ на фрармако-технологические свойства таблеток экстракта черники листья, экстракта козлятника травы и таурина (процесс прессования, однородность массы, устойчивость таблеток к раздавливанию, стираемость и время распада). С помощью гипер-греко-латинского квадрата четвертого порядка изучено влияние 6-ти качественных фракторов на основные показатели исследуемых таблеток. Построены ранжированые ряды преимуществ влияния ВВ на основные показатели таблеток экстракта черники листья, экстракта козлятника травы и таурина.

Ключевые слова: фрармако-технологические показатели таблеток; таблетки; черника обыкновенная; козлятник лекарственный; сахарный диабет.

\title{
STUDY OF THE INFLUENCE OF EXCIPIENTS ON PHARMACO-TECHNOLOGICAL PROPERTIES OF TABLETS BASED ON THE EXTRACT OF BILBERRY LEAVES, EXTRACT OF GOAT'S RUE HERBS AND TAURINE OBTAINED BY DIRECT COMPRESSION METHOD
}

\author{
O. Z. Barchuk' ${ }^{1}$ T. A. Groshovyí2, O. M. Zaliska ${ }^{1}$, V. Ja. Shalata ${ }^{3}$ \\ Danylo Halytsky Lviv National Medical University ${ }^{1}$ \\ I. Horbachevsky Ternopil StateMedical University² \\ GalychpharmPJSC ${ }^{3}$ \\ olvia2003@ukr.net
}

The aim of the work. Study of the influence of excipients on pharmaco-technological properties of the tablets with the purpose of development of a new combined pill drug with hypoglycemic activity on the basis of dry extracts of the bilberry leaves, goat's rue herbs and taurine obtained by direct compression method.

Materials and Methods. The main active substancesare dry extracts of Vacciniummyrtillus L. leaves, Galega officinalis L. Herbs, taurine and 30 excipients grouped into 6 qualitative factors according to the properties and purposes. The mathematical planning of the experiment on the basis of the $4 \times 4$ hyper-Greek-Latin square was used in the work. It makes possible to establish the relationship between the composition of the tablets and the irbasic pharmaco-technological parameters (the process of compression, uniformity of the mass, the resistance of the tablets to crushing, friability, time of disintegration), in accordance with the requirements of SPFU 2.

Results and Discussion. The influence of 30 excipients on the pharmaco-technological properties of tablets (compression process, uniformity of mass, resistance to crushing, friability, time of disintegration) on the basis of dry bilberry leaf extract, extract of goat's rue herbs and taurine was studied. The influence of 6 qualitative factors on the pharmaco-technological parameters of the studied tablets was studied with the help of a six-factor experiment of the 4x4 hyper-Greek-Latin square. Ranks of the advantages of the studied excipients were constructed for each of the indicators.

The dispersion analysis of experimental data showed that the best process for pressing tablets of bilberry leaf extract, extract of goat's rue herb and taurine is carried out with the use of parlitol 100SD + mannitol, stearin acid, neusel in UFL and sodium carboxymethyl starch. The most uniformity mass of tablets is obtained with the use of neuselinum USand neuselinum UFL, sodium carboxymethyl starch, prosolveODTG 2, magnesium stearate and lubritabe.

The most resistant to crushing tablets were obtained with the use of MCC 200, MCCburst, magnesium stearate, neuselinum US 2, sodium croskarmellose and sodium carboxymethyl starch.

The studied tablets that included MCCburst, neuselinum US 2, MCC 200, crospovidone CL 10, stearin asid and ludipress had the least friability.

The tablets based on extracts of Vacciniummyrtillus L. leaves, Galega officinalis L. herbs and taurine with the use of manit, tabletose, sodium croskarmellose, calcium carbonate, sodium stearylfumarate, MCC 102, prosolve ODTG 2 had the least disintegration time.

Conclusions. The influence of 30 excipients on the pharmaco-technological properties of leaf bilberry extract, extract of goat's rue herbs and taurine (compression process, uniformity of mass, resistance to crushing, friability, time of disintegration) have been investigated. The influence of 6 qualitative factors on the main responses (indexes) of tablets based on dry extracts of Vacciniummyrtillus L. leaves, Galega officinalis L. herbs and taurine was studied with the help of

ISSN 2312-0967. Pharmaceutical review. 2018. № 1 
Фармацевтична технологія, біофармація, гомеопатія Pharmaceutical technology, biopharmacy, homeopathy

the $4 \times 4$ hyper-Greek-Latin square. The ranks of the advantages of excipients influence on 5 responses (indexes) of tablets based ondryextractsofVacciniummyrtillusL. leaves, GalegaofficinalisL. herbsandtaurine were constructed.

Key words: pharmaco-technological properties of the tablets; tablets; bilberry; goat's rue; taurine; hypoglycemic.

\section{Список літератури}

1. Огляд лікарських рослин, які виявляють гіпоглікемічну активність / Л. В. Вронська, Н. 3. Тимофртевич, М. А. Єжнед [та ін.] // Фармацевтичний часопис. - 2013. - Вип. 2. -С. 142-148.

2. Дослідження гіпоглікемічних властивочтей сухого екстракту чорниці звичайної / Х. І. Курило, І. М. Кліщ, А. С. Вольська [та ін.] // Медична та клінічна хімія. -2016. -T. 1., № 2. - C. 38-41.

3. Фитотерапия против диабета. Травы жизни /[ Корсун В. Ф., Корсун Е. В., Трумпе Т. Е. и др.]. - Москва : ЗАО «Издательство Центрполиграфр», 2016. -С 190.

4. Актуальність розробки та створення антидіабетичних лікарських засобів на основі фрітоекстракту козлятника лікарського (Galega officinalis L.) / O. 3. Барчук, Т. А. Грошовий, Г. Ю. Яцкова [та ін.] // Фітотерапія часопис. $-2016 .-4$. -С. 41-46.

5. Зворська О. 3. Чорниця звичайна (Vaccinium myrtillus L.) - перспективна сировина для одержання лікарських засобів / О. 3. Барчук, Т. А. Грошовий // Фармацевтичний часопис. -2009. -№ 3(9). -С. 29-33.

6. Palit P. Novel weight-reducing activity of Galega officinalis in mice / P. Palit, B. L. Furman, A. I. Gray // J. Pharm. Pharmacol. - 1999. - Vol. 51. - P.1313-1319.
7. Розробка оптимального складу та технології таблеток екстракту трави козлятника, екстракту листя чорниці та таурину методом прямого пресування. Повідомлення 1. Вивчення впливу допоміжних речовин на фрармако-технологічні характеристики порошкових мас при створенні таблеток екстракту трави козлятника, екстракту трави чорниці та таурину методом прямого пресування / О. 3. Барчук, Т. А. Грошовий, О. М. Заліська [та ін.] // Фармацевтичний часопис - 2017. -№ 4 (44). -С. 30-40. 8. Experimental study of goat's rue (Galega Officinalis L.) herb and its liquid extracts / O. Z. Barchuk, R. M. Lysiuk, A. I. Denys [et al.] // The Pharma Innovation Journal. 2017. - Vol. 6 (11). - P 393-397.

9. Математичне планування експерименту при проведенні наукових досліджень в фрармації / Т. А. Грошовий, В. П. Марценюк, Л. І. Кучеренко [та ін.]. - Тернопіль : Укрмедкнига, 2008. - 367 с.

10. Державна Фармакопея України: в 3 т. / Державне підприємство «Український науковий фрармакопейний центр якості лікарських засобів». - 2-е вид. - Харків : Державне підприємство «Український науковий фрармакопейний центр якості лікарських засобів», 2015. - Т. 1. -1128 c.

\section{References}

1. Vronska LV, Tymoftevych NZ, Ezhned MA, Barchuk OZ. [Reviw of plant which exhibit hypoclycemic activity] Farmatsevt chasop.2013;2: 142-8. Ukrainian.

2. Kurylo KhI, Klishch IM, Volska IM, Barchuk OZ. [Research of hypoglycemic properties of dry extract of Vaccinium myrtillus L.]. Medical and Clinical Chemistry. 2016;18(2): 38-41. Ukrainian.

3. Korsun VF, Trumpe TE, Korsun EV, Ershov NV, Ogrenich NA. Phytotherapy against diabetes. Herbs of life. [Фитотерапия против диабета. Травы жизни] Moscow: ZAO Tsentrpoligraph Publishing House; 2016. Russian.

4. Barchuk OZ, Kurylo Khl, Hroshovyi TA, Yatskova GYu. [Actuality of development and creation of antidiabetic drugs based on fitoextract of goa's rue (Galega officinalis L.)] Phitoterapiia chasop. 2016;4: 41-6. Ukrainian.

5. Zvorska OZ, Hroshovyi TA. Vaccinium myrtillus as perspective raw materials for creating medicines. Farmatsevt chasop. 2009;3(9): 29-33. Ukrainian.

6. Palit P, Furman BL, Gray Al. Novel weight-reducing

activity of Galega officinalis in mice. J Pharm Pharmacol.1999;51: 1313-9.

7. Barchuk OZ, Groshovyi TA, Zaliska OM, Shalata VJa, Revyatsky IYu. Development of optimal composition and technology of tablets based on the exstracts of goat's rue herd, exstracts of bilberry leaves and taurine by direct compression method. Farmatsevt chasop. 2017;4(44): 30-40. Ukrainian.

8. Barchuk OZ, Lysiuk, RM, Denys Al Experimental study of goat's rue (Galega Officinalis L.) herb and its liquid extracts. The Pharma Innovation Journal. 2017;6(11): 393-7. 9. Hroshovyi TA, Martsenyuk VP, Kucherenko LI, Vronska LV, Huryeyeva CM. Mathematical planning of experiment in pharmacy. [Математичне планування експерименту в орармаціiі] Ternopil: Ternopil State Medical University; 2008. Ukrainian.

10. State Pharmacopoeia of Ukraine. [Державна Фармакопея України: в 3 т., 2-е вид.] Kharkiv: Derzhavne pidpryiemstvo «Naukovo-ekspertnyi farmakopeinyi tsentr»; 2015. Ukrainian.

Отримано 20.12.2017

ISSN 2312-0967. Фармацевтичний часопис. 2018. № 1 